\title{
The Position of Source Culture in the Current EFL Textbooks in Indonesia Reflected in 3 Research Findings
}

\author{
Maisaroh Rambe ${ }^{*}$, Laila Afni Rambe \\ State Islamic University Imam Bonjol Padang \\ maysarahrambe97@gmail.com
}

\begin{abstract}
Based on this background, the authors are interested in examining more deeply with research questions, namely why book authors tend to take source culture as material and real examples of cultural values reflected in textbooks. The research method used in this study is a qualitative research method with the type of library research. Thus the data collection method used is observation. Observations were made on three journals that have been selected as data for analysis, namely analysis of the cultural content of third grade English textbooks in Cianjur, West Java, Cultural content in Indonesian case English teaching textbooks (ELT), Analysis of cultural content in Pathway textbooks. to English for the second grade of high school. The theory used as an analytical knife is the theory of Cortazzi and Jin (1999) which examines culture. The analysis results show the authors tend to choose local culture as a teaching material, as evidenced by $13.11 \%$ in Faris journal, $45 \%$ in Kurnia journal and $19 \%$ in Nurjannah journal choose source culture as teaching material. The reason the author decides source culture as source material is that the participants of the source culture easily understand the material, the source culture is easily found in real terms, the delivery of the source culture can help preserve the culture itself so that it does not become extinct, the source culture material can broaden students' horizons because of its diversity in Indonesia. Source cultural materials can indirectly foster nature and mutual respect for cultural differences between one another.
\end{abstract}

Key words: Source Culture; Cortazzi and Jinn; ELT

\section{A. INTRODUCTION}

English is an international language that must be used by all countries in the scope of global communication. The use of English in the international field is a must. On the 
other hand, English is considered a foreign language that must be used. It is known that English cannot be separated from a culture. This indicates that English is always attached to the elements of a culture (Erfani, 2014). On this occasion the author chose the source culture as the object of study in this study. The selection of source culture as material was also written by previous researchers in the form of published research journals. The discussion about source culture is interesting to discuss considering that cultural studies are always in academic discussion. Given the wide scope of source culture, the authors limit the study by focusing on analyzing the position of source culture in writing in Indonesia. The object of analysis that is used as a reference is scientific work in the form of a journal written by Faris (2014) with the title "Look Ahead" as teaching material for class III SMA. There is source cultural content as one of the teaching materials in the book entitled "Pathway to English".By Nurjannah (2019). Furthermore class $\mathrm{X}$ students were given teaching materials with the title "English" by Kurnia (2016). In contrast to previous researchers The author focuses on examining the reasons for the author's tendency to choose local culture as teaching material. Based on the findings presented by Faris in Look Ahead that there is a tendency of $13,11 \%$ educators to choose source culture as teaching materials. According to Nurjannah findings, there are $19 \%$ and according to Kurnia 45\%. The author's tendency in choose the source material.

According to Cortazzi and Jin (1999) the material in the culture textbook is categorized of culture, namely is follows: source culture, target culture, and international culture. But researchers focus on source culture by analyzing the textbook based on this framework, culture featured in textbooks can be revealed.

Source culture is a culture that belongs to a region and reflects the social conditions of its region, there are several things that include local culture including folklore, folk songs, regional rituals, regional customs, and everything that is regional in nature. The integration of local culture into learning is very important. things that are done in an effort to instill the values contained in local culture and also at the same time to 
minimize the negative influence of culture, especially western culture brought about by globalization. The inevitable globalization must be anticipated by building a culture with the character of strengthening identity and local wisdom which is used as the basis for developing strategies for cultural preservation and development explained in the theory Cortazzi and Jin.

This study is limited to explaining the position of source culture in senior high school textbooks. This study examine based on the description above, this study is interested in conducting a study entitled "The Position of Source Culture in Current EFL Textbooks in Indonesia Reflected in 3 Research findings". Based on the background of the study, researcher formulates the problems as follows: 1.How is the position of source culture in journal? 2. Why does the writer of the book tend to take the source culture as the materials? 3.What are the real examples of cultural values reflected in the textbook?

\section{B. RESEARCH METHOD}

\section{Research Design}

Qualitative research is employed as the approach to this research. It is defined as the type of research study that investigates the quality of relationships, activities, situations, or materials. Furthermore, qualitative research is defined as research in which the researcher relies on the views of participants; asks broad, general questions; collects data consisting largely of words (or) from participants; describes and analyzes these words for themes; and conducts the inquiry in a subjective, biased manner (Creswell, 2003).

Lexy in Vitaresti (2015:42) says that qualitative descriptive is a type of research that produces descriptive data (Vitaresti, 2015). Research conducted through data collection or scientific work on the object of research or the analysis carried out to solve a problem which is basically based on a critical and in-depth study of the relevant material. In this 
study, the researcher used a qualitative approach because the data in this study came from journal accompanied by the source culture.

Content analysis is a research method for making replicable and valid inferences from data to their context, with the purpose of providing knowledge, new insights, a representation of facts and a practical guide to action (Salam, 2013). In this study, the author focuses on analyzing source culture as a source of material used by educators.

Source of Data

Table 1. Data Sources (Journal)

\begin{tabular}{|c|c|c|c|c|c|}
\hline No & Author & Title & Name of journal & Vol & No \\
\hline 1 & $\begin{array}{l}\text { Ihsan Nur } \\
\text { Iman Faris } \\
(2014) \\
\text { https://ejourn } \\
\text { al.upi.edu/ind } \\
\text { ex.php/L- } \\
\text { E/article/vie } \\
\text { w/4599 }\end{array}$ & $\begin{array}{l}\text { Culture content analysis of } \\
\text { an English textbook for } \\
\text { senior high school grade } \\
\text { three in cianjur, west java }\end{array}$ & $\begin{array}{l}\text { Jurnal of English and } \\
\text { education }\end{array}$ & 2 & 2 \\
\hline 2 & $\begin{array}{l}\text { Kurnia Citra } \\
\text { Dewi } \\
\text { (2016),et all. } \\
\text { http://syekhn } \\
\text { urjati.ac.id } \\
\end{array}$ & $\begin{array}{l}\text { Culture content in an } \\
\text { English language teaching } \\
\text { (ELT) textbook a case of } \\
\text { Indonesia }\end{array}$ & $\begin{array}{l}\text { Journal of language } \\
\text { and culture }\end{array}$ & 7 & 4 \\
\hline 3 & $\begin{array}{l}\text { Ine } \\
\text { Nurjannah, } \\
\text { (2019),etall. } \\
\text { https://digilib } \\
\text {.uns.ac.id }\end{array}$ & $\begin{array}{l}\text { An analysis of culture } \\
\text { content in the textbook } \\
\text { "PATHWAY to English" } \\
\text { for second grade in senior } \\
\text { high school }\end{array}$ & $\begin{array}{l}\text { Journal of analysis } \\
\text { culture }\end{array}$ & 4 & 1 \\
\hline
\end{tabular}

Data sources are sources that allow a researcher to obtain information or data needed in a study. Sources of data obtained from subject informants, history or other documentation. The data obtained will be filtered by which relevant researchers are not. Therefore, the data used in this study were obtained from documentation in the 
form of journals. The source of the data obtained and obtained by the researcher is obtained from various sites from Google Scholar.

\section{Data Collection Procedure}

This research is included in qualitative research using the type of library research. To obtain relevant data, the authors use data collection techniques, namely observation. Observation is observing, examining documents, whether officially published or contained in printed or electronic materials, which are related to the topics discussed.

\section{Data Analysis Procedure}

Data analysis is the process of systematically applying statistical or logical technique to describe recap and evaluate data. In this research, to answer the research question, after the data have been collected, the researcher analyzed the data systematically.

\section{FINDINGS AND DISCUSSION}

All of the above explanation are summarized in the table below:

Table 2. Journal by Kurnia

\begin{tabular}{|c|c|c|c|c|}
\hline $\begin{array}{c}\text { Title of } \\
\text { Journal }\end{array}$ & $\begin{array}{c}\text { Source } \\
\text { Culture (SC) }\end{array}$ & $\begin{array}{c}\text { Target } \\
\text { Culture (TC) }\end{array}$ & $\begin{array}{l}\text { International } \\
\text { Culture (IC) }\end{array}$ & $\begin{array}{c}\text { Page } \\
\text { Number }\end{array}$ \\
\hline \multirow{11}{*}{$\begin{array}{c}\text { Culture } \\
\text { Content in an } \\
\text { English } \\
\text { Language } \\
\text { Teaching } \\
\text { (ELT) } \\
\text { Textbook a } \\
\text { Case of } \\
\text { Indonesia }\end{array}$} & Indonesia & American & Mckay & 2 \\
\hline & Ali akbari & Australia & Xiao & 3 \\
\hline & Martono & Canada & Dehbozorgi & 3 \\
\hline & Mulfiani & New zeland & Cuningworth & 3 \\
\hline & Silvia & & $\begin{array}{c}\text { Cortazzi and } \\
\text { Jin }\end{array}$ & 3 \\
\hline & Mora & & Wallen & 4 \\
\hline & Suqirin & & Fraenkel & 7 \\
\hline & Maslak & & Yuen & 7 \\
\hline & Hardi & & Alptekin & 17 \\
\hline & Morgan & & Kafipour & 18 \\
\hline & Amalsaleh & & & 7 \\
\hline Total & 11 & 4 & 10 & \\
\hline
\end{tabular}


Table 3. Journal by Ine Nurjannah

\begin{tabular}{|c|c|c|c|c|}
\hline $\begin{array}{c}\text { Title of } \\
\text { Journal }\end{array}$ & $\begin{array}{c}\text { Source } \\
\text { Culture (SC) }\end{array}$ & $\begin{array}{c}\text { Target } \\
\text { Culture (TC) }\end{array}$ & $\begin{array}{l}\text { International } \\
\text { Culture (IC) }\end{array}$ & $\begin{array}{c}\text { Page } \\
\text { Number }\end{array}$ \\
\hline \multirow{11}{*}{$\begin{array}{l}\text { An Analysis } \\
\text { of Culture } \\
\text { Content in the } \\
\text { Textbook } \\
\text { "PATHWAY } \\
\text { to ENGLISH" } \\
\text { for Second } \\
\text { Grade in } \\
\text { Senior High } \\
\text { School }\end{array}$} & Indonesia & British & Graves & 85 \\
\hline & Erlangga & American & Karamouzian & 85 \\
\hline & Kebaya & & Yen & 87 \\
\hline & Bali & & Magogwe & 87 \\
\hline & Java & & Brown & 87 \\
\hline & Tapanuli & & Richard & 88 \\
\hline & Sanusi pane & & $\begin{array}{c}\text { Cortazzi and } \\
\text { Jin } \\
\end{array}$ & 88 \\
\hline & $\begin{array}{c}\text { Ismail } \\
\text { marzuki }\end{array}$ & & Fraenkel & 91 \\
\hline & Bandung & & Lodico & 91 \\
\hline & $\begin{array}{c}\text { Flirt pulau } \\
\text { kelapa }\end{array}$ & & & 91 \\
\hline & Moran & & & 86 \\
\hline Total & 11 & 2 & 9 & \\
\hline
\end{tabular}

Table 4. Journal by Faris

\begin{tabular}{|c|c|c|c|c|}
\hline $\begin{array}{c}\text { Title of } \\
\text { Journal }\end{array}$ & $\begin{array}{c}\text { Source } \\
\text { Culture (S C) }\end{array}$ & $\begin{array}{c}\text { Target } \\
\text { Culture (TC) }\end{array}$ & $\begin{array}{c}\text { International } \\
\text { Culture (IC) }\end{array}$ & $\begin{array}{c}\text { Page } \\
\text { Number }\end{array}$ \\
\hline \multirow{9}{*}{$\begin{array}{c}\text { Culture } \\
\text { Content } \\
\text { Analysis of an } \\
\text { English } \\
\text { Textbook for } \\
\text { Senior High } \\
\text { School Grade } \\
\text { Three in } \\
\text { Cianjur, West } \\
\text { Java }\end{array}$} & $\begin{array}{c}\text { Senior high } \\
\text { school grade } \\
\text { three in } \\
\text { Cianjur }\end{array}$ & American & $\begin{array}{c}\text { Cortazzi and } \\
\text { Jin }\end{array}$ & 14 \\
\hline & West java & British & Adaskou & 14 \\
\hline & $\begin{array}{l}\text { Air lngga } \\
\text { publisher }\end{array}$ & Canadian & Kramsch & 14 \\
\hline & Ali Akbari & Australian & Brown & 15 \\
\hline & Indonesia & Newzealand & Mc Grath & 15 \\
\hline & Hardi & & Lund & 17 \\
\hline & Morgan & & Morocco & 18 \\
\hline & Sahidudin & & Byram & 22 \\
\hline & Matsuda & & Paterson & 22 \\
\hline Total & 9 & 5 & 9 & \\
\hline
\end{tabular}


Table 6. Cultural Content in the Journal

\begin{tabular}{|c|l|c|c|c|}
\hline No & Category & $\begin{array}{c}\text { Source } \\
\text { Culture (SC) }\end{array}$ & $\begin{array}{c}\text { Target } \\
\text { Culture (TC) }\end{array}$ & $\begin{array}{c}\text { International } \\
\text { Culture (IC) }\end{array}$ \\
\hline 1 & Names & 20 & - & 28 \\
\hline 2 & Text & 10 & 11 & - \\
\hline & Total & 30 & 11 & 28 \\
\hline & Percentage & $43 \%$ & $16 \%$ & $40 \%$ \\
\hline
\end{tabular}

Referring to the table above, it is known that for the entire percentage of the total text, names and related dialogs in the data source. In the table, it can be seen that the percentage for all texts, names and dialogues related to the source culture is $43 \%$. then there is $16 \%$ referring to the target culture and then $40 \%$ being the percentage of international culture. This shows that source culture has the highest dominance in textbooks, namely 43\%. while the lowest percentage is $16 \%$. Thus it can be concluded that the source culture occupies the highest position that dominates the textbook.

\section{Discussion}

\section{Culture Position in EFL}

The definition of culture that has been previously described implies that culture influences the way of thinking, acting, feeling, and experiencing other people. This means that the same applies to students in language classes (Lange, 2011). They see and perceive people's behavior through their own cultural vision. These perceptions are transferred through language and their explanation is influenced by a person's cultural framework.

In teaching and learning practices, as stated by Gao (2006), the interdependence between language learning and cultural learning is so real that it can be concluded that language learning is cultural learning and consequently, language teaching is cultural learning. Gao further stated that foreign language teachers should be aware of the place of cultural studies in foreign language classrooms and strive to raise students' cultural awareness and improve their communication competences. 
Cultural learning has long been associated with a historical approach because language teachers come from a humanistic background. Students are made to learn facts and figures about a country's culture even though the link between culture and language is lost. The traditionally• taught culture is called 'big C' culture, which refers to "the great achievements of people reflected in history, social institutions, works of art, architecture, music and literature". Customs, traditions and practices carried out in everyday life are called 'small c' culture (Saluveer, 2004).

According to Tomalin (2008:4), culture in English is taught as a fifth language skill, in addition to listening, speaking, reading, and writing (Tomalin, 2004). He further argues that cultural teaching in ELT should include cultural knowledge (knowledge of cultural institutions, big C), cultural values (the 'soul' of the country, what is considered important), cultural behavior (knowledge of daily routines). and behavior., small c), and cultural skills (developing intercultural sensitivity and awareness, using English as a medium of interaction).

Fenner (2000: 142) states that the aim of foreign language education should be to "provide opportunities for students to develop knowledge, competence, and cultural awareness in such a way that it can lead to better understanding of foreign cultures, 'other people' and the cultures of the participants (Fenner, 2000). students, i.e. 'self' There is some confusion about how the terms cultural knowledge, awareness and competence are used in the literature on cultural teaching, therefore some clarification of these terms is needed.

Cultural knowledge, according to Byram (1989: 120), is structured and systematic information presented about other cultures that provides the 'framework' necessary to understand it (Byram 1997: 61). Tomlinson and Masuhara (2004: 6) add several more features that characterize cultural knowledge. According to them, usually external, presented by others; static, unchanged from his own experience; articulated, which are 
reduced to words that can be expressed; stereotypes; and finally, reduced, depending on the information available. These are most often presented in the form of descriptions, explanations, statistics, and generalizations as well as anecdotes and examples to illustrate generalizations.

Cultural awareness is based on other people's knowledge as well as one's own culture. However, this should not only be seen as "replacing a one-way view with a two-way view" (Pulverness 1999: 27) because the concept is much larger. Tomalin and Stempleski (1993: 5) define cultural awareness as "sensitivity to the impact of cultureinduced behavior on language use and communication". They add that it includes awareness of the behaviors induced by one's own culture, awareness of behaviors induced by other people's cultures and finally, the ability to explain the point of view of one's own culture.

Byram (1997: 60) explains more thoroughly what abilities are involved in cultural awareness According to him, this can be seen as the ability to reflect on one's cultural identity, question values and beliefs that are taken for granted and compare one's culture with the culture of one's interlocutors (Byram, 1997). Comparisons form the basis for understanding and help learners to "understand and overcome differences" (Byram 1998: 4).

Tomlinson and Masuhara (2004: 6) characterize the nature of cultural awareness in contrast to cultural knowledge. They claim that it consists of perceptions of one's own culture and that of others which are internal, that is, they develop in min d; dynamic, that is, they are constantly being added and changed; variables, which are modified from experience; multi-dimensional, which is represented through sensory images and mental images; and the last one is interactive, which is interrelated and influences each other. While cultural knowledge is mostly gained from others, cultural awareness is 
gained from personal experience either directly through overseas visits or indirectly through music, films and literature.

Competence can be defined as "the amount of knowledge, skills and characteristics that enable a person to take action" (CEF 2000: 9). In understanding other cultures, intercultural competence (also sometimes referred to as socio-cultural, Byram 2000: 9) competence and communicative competence between cultures has become the most frequently discussed. According to Byram (2000: 9, 1997: 49-54), intercultural competence involves five elements: (1) attitude: curiosity and openness, suspending distrust about one's own culture and other cultures, (2) knowledge: products and own cultural practices and other cultures, social and individual interactions, (3) interpreting and relational skills: interpreting documents or events from other cultures and relating them to documents from one's own culture, (4) discovery and interaction skills: the ability to acquire new knowledge and operate knowledge, skills and attitudes in real time communication and (5) critical cultural awareness / political education.

Cultural integration in ELT can mean developing one of these aspects discussed. What is most concerned about depends on the purpose of teaching the culture and the situations in which it is taught. In this thesis, mostly discussed about the development of knowledge and cultural awareness. The main reason for this is that, traditionally, the emphasis on cultural integration in the language classroom has been on the acquisition of cultural knowledge and, more recently, on the development of cultural awareness. In addition, both are important aspects of intercultural competence.

\section{The position of Source Culture in Journal}

Based on data obtained from the three journals as data sources, the authors hereby describe the results of the analysis by looking at the position of the source culture in the journal. Source culture in the theory of Cortazzi and Jinn in the journal found that there is a $43 \%$ tendency for the authors to choose source culture as source culture $43 \%$, 
target culture $16 \%$, and international culture $40 \%$. This shows that source culture has a tendency to dominate $43 \%$ among elements. other elements such as target culture and international culture based on the highest percentage figures obtained by the source culture compared to others, a common thread can be drawn as a result that the position of the source culture in the journal is the highest position. so that the dominant source culture of the author uses the source culture as a source material.

\section{The writers tend to Choose Source Culture as a Source of Material}

Referring to the journal article written by Faris (2014:20) there is a (13.11\%) tendency of the author to choose source culture as material. The choice of source culture material is caused by the presentation of material that is simple and easy to convey to the audience as listeners. In addition, source culture includes material that is easily understood by every layer of audience, both the learning carried out by teachers and students as implementers of teaching and learning activities.

\section{Examples of Real Values of Cultural Existing in the Book Text.}

A real example is the evidence that the author found in every journal that was used as data in this study. Real examples in the form of text can be seen from the article written by Faris which contains an understanding of the imfortance of making source culture one the materials in teaching and learning activities. Furthermore in the journal written by Kurnia there is description of the advantages of source culture when used as a source of material. Because in the explanation it is said that the source culture material provides a lot of insight that includes history, customs, food and so on. so that this will broaden the understanding of students or students. On the other hand, Nurjannah argues that the existence of mutual cultural knowledge between students will provide significant benefits. It supports a sense of mutual respect for the culture of others without having to put aside one's own culture. 
Cultural development through the provision of teaching materials in an educational institution is legalized by the Indonesian government. The enactment of the 2003 Law on the Education System legalized the provision of teaching materials for source culture. In addition, this law also states that teachers in Indonesia are required to maintain the development of students' understanding of their own culture. The wide range of English as an international language to the importance of introducing source culture through English seems to make it easy for students to use English through source culture.

In an article by Nurjannah (2019) in the form of a journal, he explains that there is a $19 \%$ complexity of using source culture as teaching materials. The reason the author choose source culture as a source material is because material is easy to understand by source culture participants, Source culture is easy to find in real terms, the delivery of source culture can help preserve the culture itself so it doesn't become extinct, source culture materials can add insight to students because of its diversity in Indonesia, source culture materials can indirectly foster the nature and mutual respect for culture differences between each other. This fact is reflected in every aspect of life. This is also supported by Dewantara's statement as the father of Indonesian education that culture is the fruit of the human mind, the result of human struggle against two strong influences: nature and society. Furthermore, Hofstede (1991) provides the view that culture is software of the mind, which means that there are rules as long as it guides students to behave well in certain groups.

In simple terms it can also be said that language is a form of culture. For example, Indonesian is Indonesian culture in communicating with other people. Language is included in the cultural heritage of the ancestors that continues to be used by the community in every generation. Knowledge of other languages enables individuals to improve culture through contact with great minds and attitudes. Culture refers to a person's way of life which consists of learned and shared patterns of behavior, values, norms, and material objects. Then, culture influences the way a person lives in society, 
behaves, thinks, and speaks. Culture in a complex sense is reflected in the source culture that represents the cultural diversity that exists in each region. Textbooks also represent source culture through student learning so that students do not forget their own culture.

Based on the explanation above, it can be seen that from the three journals there is a percentage of authors who choose source culture as teaching materials. Teaching materials categorized as local culture appear in various percentages such as education, history, travel, customs and traditions, food, norms, economy, government make-up, people figures and names. So that the selection of source culture by the author is done to make it easier for students to understand the material being taught. The tendency of writers or educators to choose source culture as a source of material has been shown to increase the response situation between educators and students.

\section{Conclusion}

Based on the descriptions in the previous chapters, the authors conclude, first, the position of source culture in the three journals occupies the highest position with $43 \%$ achievement and is followed by $16 \%$ target culture and international culture with $40 \%$ as the lowest percentage. Based on this, it can be seen that source culture is the dominant category in all journals, the prominence of source culture compared to the target culture and international culture is relevant to the three journals. this is evidenced by the presence of elements in the form of names and texts in the journal. Both source cultures as sources of material were chosen by the authors based on the effectiveness of the learning carried out. because the source culture material becomes one of the material that is easily understood by all students. Source culture material has its own advantages that are easily found in the social life of the community. third, examples of source culture in journals are divided into two categories, namely text and name. Within the scope of the text in the journal found, senior high school grade three in Cianjur, West Java, Flirt Pulau Kelapa. while the categories of names in the journals were found, sahidudin, matsuda, ali akbari, martono, mulfiani, silvia, mora, suqirin, 
hardi, morgan. Based on Cortazzi and Jinn, culture is categorized into target culture, source culture and international culture. the use of source culture as material aims to facilitate students' understanding of the material being taught the use of source culture is also useful for developing students' insights about source culture in Indonesia.

\section{CONCLUSION AND SUGGESTION}

Reviewing the research conclusion, the researcher provides suggestions regarding the source culture in the journal. It is recommended to textbook readers to interpret textbooks as proportional teaching materials in order to create a balance between aspects of source culture and foreign culture so as not to trigger the degradation of source culture. Furthermore, to all author of the upcoming edition of English textbooks. It is then recommended to the Ministry of Education and Culture of the Republic of Indonesia to continue to evaluate the curriculum, balance local content, and balance cultural content in English textbooks. To evaluate the balance of source content and balance cultural content in textbooks. The dominant cultural information in textbooks is focused on images with little text represented. Therefore, textbooks need to include more aspects of source culture to improve students' intercultural competence. Educators are advised to provide local cultural knowledge as an additional reference for students.

\section{E. REFERENCES}

Ali, M. S. (2004). The Holy Qur'an the Arabic text and English Translation, United Kingdom, Islamic International Published

Alderson, J. C. (2000). Assessing Reading, Cambridge: Cambridge University Press Besral, Martin Kustati, et.al. Cultural Contents In The Elt Textbook Prepared by The Indonesian Ministry of Education For Secondary Schools. Journal of Nusantara Studies.

Budiarti, N. I. (2014). The Readability Level of English Reading Texts for Grade VIII Students of SMP Negeri 1 Jetis Bantul in the Academic Year of 2014/2015 Byram, M.(1997) Teaching And Assessing Intercultural Communicative Competence. Clevedon: Multilingual Matters. 
Chao, T.-c. 2011. The Hidden Curriculum of Cultural Content in Internationally Published ELT Textbooks: A closer Look at New American Inside Out. The Journal of Asia TEFL, 8 (2), 189-210

Creswell, J. W, (2003), Research Design Qualitative and Quantitative and Mixed Method Approach, United States of America: California

Dian, Rini dan Indah. 2014. An Analysis of Local and Target Culture Integration in English Textbooks. Jurnal Bahasa \& Sastra, p. 30-31

Erfani, S. M. 2014. Source culture, target culture or interculture? Iranian English language teachers' perception of culture. International Journal of Language Learning and Applied Linguistics World

Faidin, (2016) Budaya Lokal Dalam Pembelajaran Sejarah untuk meningkatkan Kesadaran Sejarah di Daerah Bima. Pendidikan Pascasarjana Universitas Pendidikan Indonesia

Fahriah and Rahayu, P. S. 2016. Readability Level of-Bahasa Inggris? Textbook for the Seventh Grade Students. Journal English Education Department, Tarbiyah and Teachers Training Faculty IAIN Antasari Banjarmasin, p. 23

Faris, I. N. (2014). Cultural Content Analysis of An English Textbook for Senior High School Grade Three in Cianjur, West Java. Journal of English and Education Volume 2, number 2. https://ejournal.upi.edu/index.php/L-E/article/view/4599

Fenner, A. 2000. Cultural Awareness. In D. Newby, Approaches to Materials Design in European Textbooks: Implementing Principles of Authenticity, Learner Autonomy, Cultural Awareness (pp. 142-152)

Harmer, J. 2001. The practise of English language teaching. (3rd ed). Essex: Pearson Education

Ine Nurjanah, A. U. (2019). An Analysis of Cultural Content in the Textbook "Pathway to English" for Second Grade in Senior High School. Elt- Echo, Vol. 4 (1) https://digilib.uns.ac.id

Jhon W Creswell, 2013. Research Design (Pendekatatan Kualitatif, Kuantitatif, and Mixed), Yogyakarta:Pustaka Belajar

Kartini Kartono. 1998. Pengantar Metodologi Research, ALUMNI, Bandung

Kinasih, A. K. 2014. A Content Analysis on English Textbooks for the Tenth Graders: Look Ahead an English Course for Senior High School Students Year X and Pathway to English for Senior High School Student Grade X,English Language Education 
Study Programme from Faculty of Languages and Arts of State University Yogyakarta, p. 43

Kurnia, A, N. 2016. Culture content in an English language teaching (ELT) textbook a case of Indonesia. Surakarta. http://syekhnurjati.ac.id

Lange, K. 2011. Perspectives on Intercultural Competence: A Textbook Analysis and an Empirical Study of Teachers ' and Students 'Attitudes. Berlin: Berlin University Mahadi, T. S. T. (2012). Language and culture. (International Journal of Humanities and Social, p 230-235

Mulfianti, I, A. 2013. The Cultural Content on English Textbook used by Second Grade of Junior High School Students, English Department, Faculty of Language and Literature, Satya Wacana Christian University Salatiga

Mungki Vitaresti, 2015. Tasks Designed to Provide Classroom Activities Based On 2013Curriculum: A Content Analysis of English Textbook Pathway to English

Salam, R. P. 2013. Cultural Content Analysis of Two English Textbooks for Senior High School, English Education Department, Faculty of Language and Arts Education, Indonesia University of Education

Silvia, A. 2013. Cultural content in English Textbooks used at Madrasah Tsanawiyah in DKI Jakarta. (Master's Thesis)

Sitoresmi, W. E. 2017. A cultural content analysis of EFL textbook-Challenge series: 2, 3, and 4 published by Pearson. (Master's thesis).UIN Syarif Hidayatullah, Jakarta, Indonesia

Tomalin, B. (2008). Culture as the Fifth Language Skill. From British Council Zainal Abidin. Journal of Nusantara Studies 2021, Vol. 6 (1) 